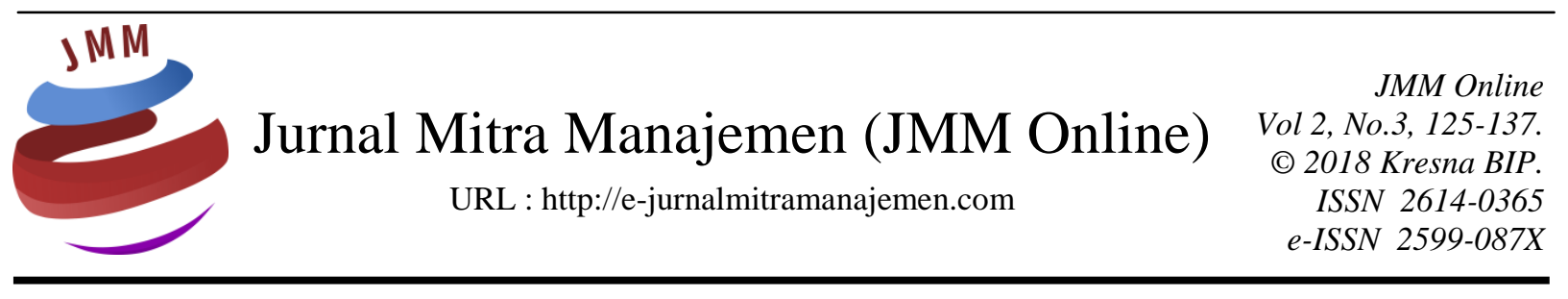

\title{
HUBUNGAN ANTARA IKLIM ORGANISASI DENGAN STRES KERJA PADA PERAWAT DI RUMAH SAKIT X JAKARTA TIMUR
}

\author{
Delon Yericho Natalio Runtu \\ Universitas Bhayangkara Jakarta Raya
}

INFORMASI ARTIKEL

Dikirim : 02 Maret 2018

Revisi pertama : 30 April 2018

Diterima : 07 Mei 2018

Tersedia online : 31 Mei 2018

Kata Kunci : Iklim Organisasi, Stres Kerja, Perawat

Email :deruntu@gmail.com

\section{ABSTRAK}

Stres kerja dapat dialami oleh siapa saja dan dipengaruhi oleh beberapa faktor, yaitu faktor lingkungan, faktor organisasi dan faktor individu. Salah satu hal yang termasuk adalah faktor organisasi yaitu iklim organisasi dimana iklim organisasi berpengaruh pada proses menciptakan lingkungan kerja yang kondusif. Salah satu pekerjaan yang paling berpotensi menciptakan stres kerja adalah perawat. Penelitian ini bertujuan untuk mengetahui hubungan antara iklim organisasi dengan stres kerja pada perawat. Subjek penelitian adalah perawat bagian rawat inap rumah sakit $X$ di Jakarta Timur yang berjumlah 150 responden. Metode yang digunakan adalah metode survey dengan penyebaran kuesioner dengan pendekatan korelasional.

Berdasarkan hasil analisis data dengan menggunakan teknik korelasi product moment, diperoleh nilai koefisien korelasi (rxy) $=-0,2 ;(p>0,05)$. Hasil tersebut menunjukkan bahwa tidak adanya hubungan antara iklim organisasi dengan stres kerja. Artinya iklim organisasi tidak berhubungan stres kerja. Berdasarkan hasil analisis variabel iklim organisasi mempunyai rerata empirik $(M E)=159.72$ dan rerata hipotetik $(M H)=171$ yang berarti iklim organisasi pada subjek penelitian tergolong sedang. Variabel stres kerja mempunyai rerata empirik $(M E)=73.50$ dan rerata hipotetik $(M H)=123.4$ yang berarti stres kerja pada subjek penelitian tergolong sedang. 


\section{PENDAHULUAN \\ Latar Belakang}

Rumah sakit yang memiliki reputasi baik adalah rumah sakit yang dapat menciptakan jasa pelayanan kesehatan yang berkualitas sehingga pasien merasa puas dengan jasa pelayanan yang diterima dan sebaliknya. Pelayanan kesehatan yang berkualitas sangat dipengaruhi oleh sumber daya manusia yang ada didalamnya, salah satunya adalah tenaga keperawatan.

Gillies (2000) menyatakan bahwa perawat merupakan tenaga kesehatan yang sangat penting. Hal ini disebabkan karena perawat berada di sisi pasien 24 jam sehari selama pasien dirawat di rumah sakit. Banyaknya tuntutan dari pasien yang dirawat dan menghadapi pasien dalam kondisi kritis seringkali membuat perawat mudah untuk mengalami stres.

Stres dapat dialami oleh siapa saja dan dalam berbagai kondisi maupun jenis pekerjaannya. Namun demikian salah satu pekerjaan yang paling berpotensi menciptakan stres kerja adalah perawat. Menurut Wong, et.al (2001) profesi perawat identik dengan stres kerja, turnover yang tinggi dan ketidakpuasan kerja. Hal senada juga dikatakan oleh Auerbach \& Gramling (1998) yang menyebutkan bahwa dokter dan perawat memiliki tingkat stres kerja yang tinggi. Hall (2004) menambahkan bahwa tingkat stres kerja yang dialami perawat yang bekerja di rumah sakit sedemikian tinggi sehingga menimbulkan banyak respon negatif yang merugikan individu tersebut. Bahkan apabila perawat mengalami stres kerja dan stres tersebut tidak dikelola dengan baik, maka akan membahayakan pasien (Jennings, dalam Yana, 2014).

Menurut Robbins (2008), timbulnya stres dipengaruhi oleh beberapa faktor, yaitu faktor lingkungan, faktor organisasi dan faktor individu. Dari uraian tersebut, dapat disimpulkan bahwa terdapat beberapa hal dari lingkungan pekerjaan yang dapat mempengaruhi stres kerja karyawan. Salah satu hal yang termasuk adalah faktor organisasi yaitu iklim organisasi dimana iklim organisasi berpengaruh pada proses menciptakan lingkungan kerja yang kondusif.

Pada umumnya setiap organisasi mempunyai kondisi lingkungan kerja yang berbeda-beda. Apabila seseorang berada dalam suatu organisasi maka individu tersebut secara psikologis akan mempersepsikan adanya kondisi tertentu mengenai lingkungan organisasi dimana ia bekerja. Kondisi lingkungan dari suatu organisasi ataupun perusahaan tempat seseorang bekerja akan mempengaruhi pandangan tentang organisasi tersebut, selanjutnya dapat mempengaruhi sikap orang-orang yang berada didalamnya, baik sikap terhadap atasan, teman sekerja maupun terhadap pekerjaannya. Lingkungan organisasi yang secara psikologis mempunyai arti bagi anggotaanggotanya disebut sebagai lingkungan internal atau secara lebih spesifik dikenal dengan istilah iklim organisasi. Menurut Lunenburg \& Ornstein (dalam Wirawan, 2008) mengemukakan bahwa iklim organisasi ialah suatu kualitas lingkungan total dalam suatu organisasi yang ditunjukkan dengan bermacam-macam sifat antara lain: terbuka, sibuk, hangat, santai, informal, dingin, impersonal, bermusuhan, kaku, dan tertutup.

Steers (dalam Idrus, 2008) menyatakan iklim organisasi adalah suatu kepribadian organisasi seperti apa yang dilihat para anggotanya. Dengan demikian menurut Steers iklim organisasi tertentu adalah iklim yang dilihat oleh para pegawai 
dalam organisasi tersebut. Dari pendapat ini dapat disimpulkan bahwa iklim organisasi suatu organisasi terletak pada persepsi pegawainya.

Iklim organisasi berpengaruh besar pada proses menciptakan lingkungan kerja yang kondusif, sehingga dapat menciptakan kerja sama yang harmonis pada setiap anggotanya di dalam suatu organisasi. Iklim organisasi yang positif akan menciptakan lingkungan kerja yang kondusif sehingga membuat para pekerja dapat terhindar dari stres kerja, sebaliknya jika iklim organisasi yang dirasakan oleh para pekerja itu negatif, maka akan membuat para pekerja akan mengalami stres kerja sehingga akan berdampak buruk pada lingkungan kerja dan individu itu sendiri.

\section{Rumusan Masalah}

Berdasarkan uraian latar belakang diatas, maka dapat dirumuskan sebuah permasalah yaitu untuk melihat apakah terdapat hubungan antara iklim organisasi dengan stres kerja pada perawat di rumah sakit X Jakarta.

\section{Tujuan Penelitian}

Adapun penelitian ini bertujuan untuk mengetahui hubungan antara iklim organisasi dengan stres kerja pada perawat di rumah sakit X Jakarta.

\section{Manfaat Penelitian}

Manfaat dari penelitian ini adalah sebagai berikut:

\section{Manfaat Teoritis}

Penelitian ini diharapkan dapat memberi masukan melalui tambahan data empiris yang telah teruji secara ilmiah bagi pengembangan ilmu pengetahuan terutama Psikologi Industri dan Organisasi, khususnya yang berkaitan dengan stres kerja yang disebabkan karena iklim organisasi.

\section{Manfaat Praktis}

Penelitian ini diharapkan dapat berguna bagi perusahaan, khususnya pihak rumah sakit sebagai dasar untuk menentukan strategi dan langkah-langkah yang tepat dalam menciptakan iklim organisasi yang kondusif dalam bekerja sehingga para perawat dapat terhindar dari stres di tempat kerjanya melalui pengelolaan stres yang baik.

\section{KAJIAN PUSTAKA \\ Stres Kerja}

Stres kerja adalah suatu kondisi ketegangan yang mempengaruhi proses berpikir, emosi, dan kondisi seseorang, hasilnya stres yang terlalu berlebihan dapat mengancam kemampuan seseorang untuk menghadapi lingkungan dan pada akhirnya akan mengganggu pelaksanaan tugas-tugasnya (Handoko, 2008).

Menurut Spielberger (dalam Handoko, 2008) mendefinisikan stres adalah tuntutan-tuntutan eksternal yang mengenai seseorang, misalnya objek-obyek dalam lingkungan atau suatu stimulus yang secara objektif adalah berbahaya. Stres juga biasa diartikan sebagai tekanan, ketegangan atau gangguan yang tidak menyenangkan yang berasal dari luar diri seseorang. 
Menurut Gibson Ivancevich (dalam Hermita, 2011) "Stres sebagai suatu tanggapan adaktif, ditengahi oleh perdebatan individual dan/atau proses psikologis, yaitu suatu konsekuensi dari setiap kegiatan (lingkungan), situasi, atau kejadian eksternal yang membebani tuntutan psikologis atau fisik yang berlebihan terhadap seseorang".

\section{Sumber-Sumber Stres Kerja}

Osipow dan Spokane (dalam Mavis, 2011) mengidentifikasi sumber-sumber stres sebagai ambiguitas peran, peran berlebihan, insufisiensi peran, batasan peran, lingkungan fisik dan tanggung jawab.

1. Ambiguitas Peran (Role Ambiguity)

Ambiguitas peran terjadi ketika prioritas, harapan dan kriteria evaluasi tidak jelas kepada karyawan. Hal ini juga mencakup situasi di mana tidak ada panduan yang jelas, tidak ada standar kinerja dan tidak ada konsekuensi yang jelas. Osipow dan Spokane menunjukkan bahwa ambiguitas peran terjadi karena individu tidak yakin tentang tindakan apa yang harus dilakukan dan keputusan apa yang harus diambil. Ambiguitas peran dapat digambarkan secara umum sebagai hasil dari individu mengenai informasi yang cukup tentang/peran tugasnya.

2. Peran berlebihan (Role Overload)

Role overload adalah sejauh mana tuntutan peran yang dirasakan oleh responden sebagai sumber informasi pribadi dan melebihi tempat kerja dan ketidakmampuan mereka dianggap untuk mencapai beban kerja yang diharapkan. Peran yang berlebihan dapat dilihat sebagai berkaitan dengan kinerja suatu jumlah tertentu bekerja dalam jangka waktu tertentu dan itu adalah pengalaman ketika seorang individu memutuskan untuk menyesuaikan diri dengan beberapa tugas dan menolak beberapa dalam jangka waktu tertentu.

3. Kekurangan beban peran (Role Insuffiency)

Yang dimaksud dengan role insuffiency sebagai tingkat tuntutan pekerjaan yang berada di bawah kemampuan sumber daya pribadi, dan sejauh mana individu terlalu mudah menyelesaikan tugasnya sehingga tidak memiliki tantangan akan tugasnya. Hal ini dapat dilihat dari sejauh mana pelatihan, pendidikan, keahlian, pengalaman individu melampaui jauh diatas tuntutan pekerjaannya. Lingkungan pekerjaan yang memiliki karakteristik kekurangan beban peran akan membuat frustasi individu didalamnya yang mempersepsikan dirinya memiliki kapabilitas dalam bekerja dengan baik.

4. Batasan peran (Role Boundary)

Stres yang diakibatkan yang telah mereka lakukan, merasakan ketidakjelasan dalam hal perintah dan memiliki lebih dari satu orang yang dapat memberikan perintah kepada mereka.

5. Peran tanggung jawab (Work Responsibility)

Work responsibility sebagai tanggung jawab individu untuk kinerja dan kesejahteraan orang lain di tempat kerja. Teori stres kerja mengidentifikasi dua jenis tanggung jawab peran yaitu 1) tanggung jawab terhadap orang-orang dan 2) tanggung jawab terhadap hal-hal. Namun, sementara tidak banyak penelitian telah dilakukan pada jenis tanggung jawab untuk hal-hal, ini menunjukkan bahwa 
tanggung jawab terhadap hal-hal mungkin tidak menjadi sumber yang baik dari stressor kerja.

6. Lingkungan Fisik (Physical Environment)

Kondisi kerja pekerjaan telah dikaitkan dengan kesehatan fisik dan mental. Lingkungan fisik dapat menjadi sumber stres mencakup paparan suhu kamar panas, sering menyendiri cahaya dan zat beracun berbahaya. Ditemukan bahwa kesehatan mental yang buruk terkait langsung dengan kondisi kerja tidak menyenangkan, upaya fisik dan kecepatan dalam kinerja dan berlebihan, jam nyaman (misalnya shift).

\section{Faktor-Faktor Penyebab Stres Karyawan}

Menurut Hasibuan (2012) faktor-faktor penyebab stres karyawan, antara lain sebagai berikut:

1. Beban kerja yang sulit dan berlebihan.

2. Tekanan dan sikap pemimpin yang kurang adil dan wajar.

3. Waktu dan peralatan kerja yang kurang memadai.

4. Konflik antara pribadi dengan pimpinan atau kelompok kerja.

5. Balas jasa yang terlalu rendah.

6. Masalah-masalah keluarga seperti anak, istri, mertua, dan lain-lain.

\section{Stres Kerja pada Perawat}

Menurut Fatma, Gafar, dan Alkader (2011) faktor yang mempengaruhi stres perawat diantaranya adalah faktor sosio-demografi, usia, tingkat pendidikan, status perkawinan, gaji, tempat tinggal, pengalaman bekerja, jadwal kerja, masalah kesehatan, lingkungan kerja, paparan kebisingan peralatan medis, kondisi pasien, kematian pasien, konflik dengan dokter, konflik dengan perawat lain.

Dan masih menurut Fatma, Gafar dan Alkader (2011) yang menjadi sumber stres terbesar yaitu konflik interpersonal $(51,6 \%)$, yang terakhir adalah konflik stres antar pribadi $(35,6 \%)$.

\section{Iklim Organisasi}

Menurut Wirawan (2008) iklim organisasi adalah persepsi anggota organisasi (secara individual atau kelompok) dan mereka yang secara tetap berhubungan dengan organisasi mengenai apa yang ada atau terjadi di lingkungan internal organisasi secara rutin, yang mempengaruhi sikap dan perilaku organisasi dan kinerja anggota organisasi yang kemudian menentukan kinerja organisasi.

Menurut Davis dan Newstrom (dalam Wirawan, 2008), iklim organisasi adalah sebuah konsep yang menggambarkan suasana internal lingkungan organisasi yang dirasakan anggotanya selama mereka beraktivitas dalam rangka tercapainya tujuan organisasi. 


\section{Dimensi-Dimensi Iklim Organisasi}

Kolb \& Rubin (dalam Wirawan, 2008) memberikan tujuh dimensi yang dapat menentukan iklim organisasi, yaitu :

a. Konformitas ; yaitu seberapa jauh pegawai mematuhi peraturan-peraturan atau kebijakan-kebijakan yang telah ditetapkan oleh pihak perusahaan.

b. Tanggung jawab ; yaitu pegawai merasa bahwa mereka diberi tanggung jawab untuk melaksanakan pekerjaan demi tujuan organisasi dan dapat mengambil keputusan dan memecahkan persoalan.

c. Standar pelaksanaan pekerjaan ; yaitu bagaimana organisasi menetapkan tujuan yang menantang dan mengutamakan kualitas pelaksanaan dan produksi.

d. Imbalan ; yaitu pegawai merasa dihargai, mendapat imbalan dengan baik, tidak hanya dikritik dan diabaikan jika melakukan sesuatu yang salah.

e. Kejelasan organisasi ; yaitu pegawai merasa bahwa segala sesuatunya diorganisir dengan baik, tujuan organisasi dirumuskan dengan jelas dan tidak membingungkan.

f. Hubungan interpersonal dan semangat kelompok ; yaitu pegawai saling mempercayai, saling membantu dan adanya hubungan baik antar pegawai di dalam lingkungan organisasi.

g. Kepemimpinan ; yaitu sejauhmana kepemimpinan yang ada di dalam organisasi diterima atau ditolak pegawainya.

\section{Faktor-Faktor Yang Mempengaruhi Iklim Organisasi}

Menurut Menurut Asmar (dalam Wirawan, 2008), terdapat lima faktor yang mempengaruhi iklim organisasi, yaitu sebagai berikut:

a. Penempatan Personalia

Masalah penempatan personalia atau penempatan sangat penting, karena apabila terjadi kesalahan dalam penempatan dapat menjadikan perilaku pegawai menjadi terganggu dan pada akhirnya bisa merusak iklim organisasi. Dalam penempatan seorang pemimpin hendaknya melihat berbagai aspek atau kondisi seperti, spesialisasi yang dimiliki, kegemaran, keterampilan dan pengalaman watak.

b. Pembinaan Hubungan Komunikasi

Dalam lingkungan organisasi bahwasanya tidak luput dari proses komunikasi, dalam kehidupan sehari-hari komunikasi sangat berperan dan iklim organisasi tercipta karena adanya komunikasi. Hubungan yang dibangun bersifat formal dan non formal.

c. Pendinasan dan Penyelesaian Konflik

Setiap organisasi akan mengalami perubahan atau perkembangan dalam setiap aspeknya seiring dengan perubahan lingkungan. Proses perubahan ini sangatlah penting untuk mengantisipasi supaya tidak terjadi stagnasi bahkan kemunduran organisasi. Peran pimpinan dalam hal ini yaitu membuat para personil/pegawai menjadi lebih dinamis dan mampu mendukung kemajuan organisasi. Untuk itu pimpinan perlu untuk menciptakan suatu kondisi yang dinamis dengan cara memberi kebebasan pada pegawai untuk mengembangkan kreativitasnya dan merealisasikan ide-ide nya. 
d. Pengumpulan dan Pemanfaatan informasi

Informasi memegang peranan yang penting dalam sebuah organisasi sebagai penghubung antara berbagai bagian organisasi sehingga tercipta keutuhan organisasi. Informasi sangat bermanfaat bagi organisasi terutama dalam penyusunan program kerja organisasi, mendukung kelancaran penggunaan metode kerja dan sebagai alat kontrol atau pengawasan.

e. Kondisi Lingkungan

Kondisi lingkungan kerja sering disebut juga sebagai suasana atau keadaan dalam kerja. Adapun yang dimaksud hal ini yaitu mencakup keadaan fasilitas atau sarana yang ada, misalnya ruangan untuk pimpinan, ruang rapat, lobi, ruang kerja pegawai, ruang tamu dan lain-lain. Kondisi fasilitas ini sebenarnya tidak langsung memengaruhi sehat tidaknya iklim kerja tetapi memberikan efek terhadap suasana hati pegawai yang ada di dalamnya.

\section{METODE PENELITIAN}

Variabel yang digunakan dalam penelitian ini adalah :

1. Variabel Bebas : Iklim Organisasi

2. Variabel Terikat : Stres Kerja

\section{Definisi Operasional Variabel Penelitian}

Iklim Organisasi adalah serangkaian keadaan lingkungan kerja yang dipersepsikan dan dirasakan secara langsung atau tidak langsung oleh karyawan dan dianggap mampu mempengaruhi perilaku karyawan.

Stres Kerja adalah kondisi pada individu yang terjadi karena adanya interaksi antara individu dengan lingkungan tempat kerjanya, dimana tuntutan dari lingkungan kerja melampaui batas kemampuan individu sehingga membawa perubahan secara fisiologis, psikologis dan perilaku.

\section{Subjek Penelitian}

Subjek dalam penelitian ini adalah 150 orang perawat yang bekerja pada RS. X Jakarta. Pengambilan sampel pada penelitian ini menggunakan teknik purposive sampling. Purposive sampling adalah pemilihan sekelompok subjek karena mereka dikatakan mampu menyediakan informasi yang dibutuhkan dan juga karena mereka memiliki kriteria sesuai dengan yang diinginkan oleh peneliti (Sugiyono, 2014). Kriteria-kriteria tersebut bisa didasarkan atas ciri-ciri atau sifat-sifat tertentu yang dipandang mempunyai sangkut paut yang erat dengan ciri-ciri atau sifat-sifat populasi yang sudah diketahui sebelumnya (Periantalo, 2017).

\section{Tempat dan Waktu Penelitian}

Tempat penelitian ini di kota Jakarta. Sedangkan waktu penelitian dimulai dari 15 Juni 2017 - 27 September 2017. 


\section{Pengambilan Sampel}

Teknik pengumpulan data yang digunakan dalam penelitian ini adalah dengan metode kuesioner. Metode kuesioner ini menggunakan skala Likert, yaitu sejumlah pertanyaan tertulis yang digunakan untuk memperoleh informasi dari responden dalam arti laporan tentang pribadinya atau hal-hal yang ia ketahui (Sugiyono, 2014). Dengan demikian terdapat 2 buah kuesioner yang terdiri dari Skala Iklim Organisasi dan Skala Stres Kerja. Adapun untuk melihat adanya hubungan antara Iklim Organisasi dengan Stres Kerja maka analisa data dalam penelitian ini dengan menggunakan teknik analisis korelasi product moment dari Karl Pearson melalui bantuan program SPSS v. 23.0 for windows.

\section{Validitas dan Reliabilitas}

Validitas sebuah tes menyangkut apa yang diukur dan seberapa baik tes itu bisa mengukur (Azwar, 2009). Instrumen yang memiliki validitas yang tinggi adalah instrumen yang menjalankan fungsi ukurnya atau memberikan hasil ukur yang sesuai dengan maksud dilakukannya pengukuran tersebut (Azwar, 2009). Oleh karena itu, validitas berarti bahwa instrumen penelitian mampu membuktikan kemampuannya dalam mengungkapkan sesuatu atau yang diamati oleh peneliti, sesuai dengan kenyataan yang sesungguhnya (Notoatmodjo, 2010). Dengan mempergunakan instrumen penelitian yang memiliki validitas tinggi, hasil penelitian mampu menjelaskan masalah penelitian sesuai dengan keadaan atau kejadian yang sebenarnya. Reliabilitas adalah tingkat kemampuan instrumen penelitian untuk mengumpulkan data secara tetap dari kelompok individu (Periantalo, 2017). Menurut Azwar (2009), konsep yang dimiliki oleh reliabilitas sebagai suatu alat ukur adalah apabila alat ukur tersebut bersifat konsisten, stabil, dapat memprediksi dan akurat. Notoatmodjo (2010) menambahkan keterangan tersebut dengan mengatakan bahwa reliabilitas menunjukkan sejauh mana hasil pengukuran dengan alat tersebut dapat dipercaya.

\section{HASIL PENELITIAN DAN PEMBAHASAN \\ Hasil Penelitian \\ 1. Uji Validitas}

Dibawah ini adalah hasil perhitungan validitas dari skala iklim organisasi, skala stres kerja dan skala kepuasan kerja.

a. Skala Iklim Organisasi

Uji validitas pada item-item skala ini adalah sebagai berikut :

- Untuk dimensi konformitas, validitas item bergerak dari 0,285 sampai dengan 0,343 . Pada dimensi ini terdapat item-item yang gugur, yaitu item nomor 8 , 15 , dan 22.

- Untuk dimensi tanggung jawab, validitas item bergerak dari 0,285 sampai dengan 0,378. Pada dimensi ini terdapat item-item yang gugur, yaitu item nomor 23 dan 30.

- Untuk dimensi standar pelaksanaan pekerjaan, validitas item bergerak dari 0,169 sampai dengan 0,524. Pada dimensi ini terdapat item yang gugur, yaitu item nomor 31. 
- Untuk dimensi imbalan, validitas item bergerak dari 0,242 sampai dengan 0,592 .

- Untuk dimensi kejelasan organisasi, validitas item bergerak dari 0,274 sampai dengan 0,599. Pada dimensi ini terdapat item-item yang gugur, yaitu item nomor 12 dan 19.

- Untuk dimensi hubungan interpersonal dan semangat kelompok, validitas item bergerak dari 0,448 sampai dengan 0,582.

- Untuk dimensi kepemimpinan, validitas item bergerak dari 0,279 sampai dengan 0,497. Pada dimensi ini terdapat item item yang gugur, yaitu item nomor 14.

Secara jelasnya distribusi item yang valid dapat dilihat pada tabel dibawah ini :

Tabel 1. Distribusi Item Skala Iklim Organisasi

\begin{tabular}{|l|l|l|l|}
\hline No. & Dimensi & Nomor Item & Total \\
\hline 1 & Konformitas & 1,29 & 2 \\
\hline 2 & Tanggung jawab & $2,9,16$ & 3 \\
\hline 3 & Standar pelaksanaan pekerjaan & $3,10,17,24,36$ & 5 \\
\hline 4 & Imbalan & $4,11,18,25,32$ & 5 \\
\hline 5 & Kejelasan organisasi interpersonal dan & $6,13,20,27,34$ & 5 \\
\hline 6 & $\begin{array}{l}\text { Hubungan } \\
\text { semangat kelompok }\end{array}$ & $7,21,28,35$ & 4 \\
\hline 7 & Kepemimpinan & $\mathbf{2 7}$ \\
\hline \multicolumn{2}{|c|}{ T O T A L } & \\
\hline
\end{tabular}

Sumber : Hasil Penelitian, diolah (2017)

Berdasarkan tabel diatas dapat diketahui bahwa untuk skala iklim organisasi, dari 36 item yang diujicobakan, ternyata item yang gugur berjumlah 9 sehingga item yang sahih atau valid berjumlah 27 item.

b. Skala Stres Kerja

Uji validitas pada item-item skala ini adalah sebagai berikut :

- Untuk dimensi beban kerja yang berlebihan, validitas item bergerak dari 0,473 sampai dengan 0,667.

- Untuk dimensi kesulitan menjalin hubungan dengan staf lain, validitas item bergerak dari 0,419 sampai dengan 0,649.

- Untuk dimensi kesulitan dalam merawat pasien kritis, validitas item bergerak dari 0,487 sampai dengan 0,675.

- Untuk dimensi berurusan dengan pengobatan atau perawatan pasien, validitas item bergerak dari 0,520 sampai dengan 0,750 .

- Untuk dimensi merawat pasien yang gagal untuk membaik, validitas item bergerak dari 0,461 sampai dengan 0,725.

Secara jelasnya distribusi item yang valid dapat dilihat pada tabel dibawah ini :

Tabel 2. Distribusi Item Skala Stres Kerja

\begin{tabular}{|l|l|l|l|}
\hline No. & Dimensi & Nomor Item & Total \\
\hline $\mathbf{1}$ & Beban kerja yang berlebihan & $1,6,11,16,21,25$ & 6 \\
\hline $\mathbf{2}$ & Kesulitan menjalin hubungan dengan staf lain & $2,7,12,17,22,26$ & 6 \\
\hline
\end{tabular}


Lanjutan Tabel 2. Distribusi Item Skala Stres Kerja

\begin{tabular}{|l|l|l|l|}
\hline $\mathbf{3}$ & Kesulitan dalam merawat pasien kritis & $3,8,13,18$ & 4 \\
\hline $\mathbf{4}$ & $\begin{array}{l}\text { Berurusan dengan pengobatan atau perawatan } \\
\text { pasien }\end{array}$ & $4,9,14,19,23$ & 5 \\
\hline $\mathbf{5}$ & Merawat pasien yang gagal membaik & $5,10,15,20,24$ & 5 \\
\hline \multicolumn{2}{|c|}{ T O T A L } & $\mathbf{2 6}$ \\
\hline
\end{tabular}

Sumber : Hasil Penelitian, diolah (2017)

\section{Pembahasan}

Penelitian ini berusaha untuk melihat adanya hubungan iklim organisasi dengan stres kerja pada perawat. Berdasarkan hasil uji statistik teknik korelasi product moment dalam penelitian ini, diperoleh nilai koefesien iklim organisasi dengan stres kerja adalah rxy $=-.0 .2$ dan $\mathrm{p}=0.000$ lebih kecil dari 0.05. Maka dapat disimpulkan bahwa tidak terdapat hubungan yang signifikan antara iklim organisasi dengan stres kerja pada perawat. Dengan demikian hipotesis alternative (Ha) ditolak dan hipotesis nol (Ho) diterima.

Tabel 3. Hasil Uji Hubungan

\begin{tabular}{|llll|}
\hline Variabel & Simpangan Baku & Nilai Korelasi & Signifikansi \\
\hline Iklim Organisasi & 19.4 & -0.2 & $>0.05$ \\
Stres Kerja & 24.2 & -0.2 & $>0.05$ \\
\hline
\end{tabular}

Sumber : Hasil Penelitian, diolah (2017)

Tabel 4. Frekuensi dan Kategorisasi Berdasarkan Suku

\begin{tabular}{|c|c|c|c|c|c|}
\hline Suku & $\mathbf{N}$ & $\begin{array}{l}\text { Mean Iklim } \\
\text { Organisasi }\end{array}$ & $\begin{array}{l}\text { Kategorisasi } \\
\text { Iklim Organisasi }\end{array}$ & $\begin{array}{ll}\text { Mean } & \text { Stres } \\
\text { Kerja } & \end{array}$ & $\begin{array}{l}\text { Kategorisasi } \\
\text { Stres Kerja }\end{array}$ \\
\hline Batak & 127 & 162.3 & Sedang & 75 & Sedang \\
\hline Non-Batak & 23 & 145 & Sedang & 65.5 & Sedang \\
\hline
\end{tabular}

Sumber : Hasil Penelitian, diolah (2017)

Berdasarkan rentang batas mean empirik, diketahui bahwa kondisi iklim organisasi di tempat kerja perawat termasuk dalam kategori sedang. Hal ini dapat terjadi karena adanya dominasi etnis tertentu. Seperti diketahui bahwa perawat di RS X Jakarta mayoritas berasal dari etnis Batak yaitu sebanyak 127 orang atau 84\% sedangkan sisanya yaitu sebanyak 23 orang atau $16 \%$ adalah berasal dari etnis nonBatak. Kondisi tempat kerja yang didominasi oleh etnis Batak, bagi sebagian besar orang Batak dirasakan bukan merupakan suatu ancaman melainkan justru membuat mereka merasa lebih nyaman dalam bekerja karena menganggap tempat kerjanya seperti "rumah" sendiri. Sebaliknya bagi etnis non-Batak hal ini dapat membuat ketidaknyamanan terutama bila terlibat konflik dengan rekan kerja yang berasal dari etnis Batak. Sejalan dengan itu, Higgins (dalam Idrus, 2008) menyatakan bahwa salah satu faktor yang berpengaruh terhadap iklim organisasi adalah kelompok, dan dalam kasus ini kelompok yang dimaksud adalah adanya kelompok yang berkembang berdasarkan kesamaan etnis.

Berdasarkan rentang batas mean empirik, diketahui bahwa stres kerja yang dialami oleh perawat pada RS X Jakarta termasuk dalam kategori sedang. Pheasant (dalam Fatma, Gafar, \& Alkader, 2011) mengatakan bahwa faktor-faktor yang 
berhubungan dengan tugas, interpersonal, maupun lingkungan merupakan faktor yang potensial untuk menjadi sumber stress, seperti ada pasien yang meninggal atau perlakuan kasar dari pasien, namun karena perawat merasa bahwa kondisi kerja dan rekan kerja sangat mendukung pekerjaannya maka tingkat stres mereka tidak tinggi. Hal ini diketahui penulis dari hasil wawancara dengan beberapa orang perawat.

Tabel 5. Hasil Wawancara dari Perawat di Rumah Sakit X di Jakarta

\begin{tabular}{|c|c|c|c|c|c|}
\hline Variabel & Bangsal & $\mathbf{N}$ & Rerata & $\begin{array}{l}\text { Std. } \\
\text { deviation }\end{array}$ & Kategori \\
\hline \multirow{10}{*}{ Iklim } & Ruang UGD & 15 & 157,2 & 10,7 & Sedang \\
\hline & Ruang D & 6 & 159,6 & 15,2 & Sedang \\
\hline & Ruang OK & 7 & 163,4 & 10,6 & Sedang \\
\hline & Ruang G & 4 & 158,2 & 14,9 & Sedang \\
\hline & Ruang E & 17 & 154,2 & 16,7 & Sedang \\
\hline & Ruang C & 7 & 158,8 & 7,5 & Sedang \\
\hline & Ruang B & 8 & 161,5 & 20,9 & Sedang \\
\hline & Ruang VIP & 4 & 171 & 25,4 & Tinggi \\
\hline & Ruang A & 27 & 156,2 & 18,5 & Sedang \\
\hline & Ruang ICU & 55 & 162,4 & 24,1 & Sedang \\
\hline \multicolumn{2}{|c|}{ TOTAL } & 150 & 159,7 & 19,4 & Sedang \\
\hline \multirow{10}{*}{$\begin{array}{l}\text { Stres } \\
\text { Kerja }\end{array}$} & Ruang UGD & 15 & 69,8 & 23,1 & Sedang \\
\hline & Ruang D & 6 & 44,1 & 9,2 & Rendah \\
\hline & Ruang OK & 7 & 60,2 & 21,5 & Sedang \\
\hline & Ruang G & 4 & 47,7 & 13,5 & Rendah \\
\hline & Ruang E & 17 & 66,8 & 15,6 & Sedang \\
\hline & Ruang C & 7 & 63,2 & 14,2 & Sedang \\
\hline & Ruang B & 8 & 81 & 35,9 & Sedang \\
\hline & Ruang VIP & 4 & 38 & 8,3 & Rendah \\
\hline & Ruang A & 27 & 88,8 & 10,1 & Sedang \\
\hline & Ruang ICU & 55 & 78,5 & 25,3 & Sedang \\
\hline \multicolumn{2}{|c|}{ TOTAL } & 150 & 73,50 & 24,17 & Sedang \\
\hline
\end{tabular}

Sumber : Hasil Penelitian, diolah (2017)

Hasil penelitian lain juga menemukan bahwa perawat yang bekerja diruang VIP memiliki persepsi yang sangat baik mengenai kondisi lingkungan kerjanya. Hal ini disebabkan karena di ruang VIP, biasanya perawat merawat pasien dengan kondisi yang sudah lebih baik. Sehingga stres kerja yang dialami oleh perawat yang bekerja diruang VIP pun cenderung rendah.

Tabel 6. Group Statistics

\begin{tabular}{|ll|l|l|l|l|}
\hline & Pendidikan & $\mathrm{N}$ & Mean & Std. Deviation & Std. Error Mean \\
\hline Nilai & Diploma & 143 & 73,7552 & 24,28563 & 2,03087 \\
& Sarjana & 7 & 68,4286 & 22,82438 & 8,62681 \\
\hline
\end{tabular}

Sumber : Hasil Penelitian, diolah (2017) 
Tabel 7. Independent Samples Test

\begin{tabular}{|l|l|l|l|l|l|l|}
\hline \multicolumn{2}{|c|}{} & \multicolumn{2}{|c|}{$\begin{array}{c}\text { Levene's Test for } \\
\text { Equality of Variances }\end{array}$} & \multicolumn{3}{c|}{ t-test for Equality of Means } \\
\cline { 2 - 7 } & F & Sig. & t & df & $\begin{array}{l}\text { Sig. (2- } \\
\text { tailed) }\end{array}$ \\
\hline Nilai & $\begin{array}{l}\text { Equal } \\
\text { variances } \\
\text { assumed }\end{array}$ &, 723 &, 397 &, 568 & 148 &, 571 \\
\cline { 2 - 7 } & $\begin{array}{l}\text { Equal } \\
\text { variances } \\
\text { not } \\
\text { assumed }\end{array}$ & &, 601 & 6,683 &, 568 \\
\hline
\end{tabular}

Sumber : Hasil Penelitian, diolah (2017)

Berdasarkan hasil uji t dalam penelitian ini, diketahui bahwa tidak terdapat perbedaan stres kerja antara perawat yang memiliki pendidikan diploma tiga dengan perawat yang berpendidikan strata satu. Adapun stres kerja yang dialami oleh perawat baik yang berpendidikan diploma maupun strata satu masuk ke dalam kategori sedang. Dengan demikian tingkat stres pada subyek penelitian tidak dapat diuji berdasarkan tingkat pendidikan.

Bagi penelitian selanjutnya diharapkan agar dapat menemukan atau mengikutsertakan variabel-variabel lain yang dapat mempengaruhi stres kerja seperti dukungan sosial, budaya organisasi, disiplin kerja dan sebagainya.

\section{KESIMPULAN DAN SARAN Kesimpulan}

Berdasarkan hasil analisis yang telah dilakukan, diketahui bahwa tidak terdapat hubungan antara iklim organisasi dengan stres kerja. Artinya bahwa iklim organisasi tidak memiliki hubungan dengan stres kerja pada perawat di rumah sakit X Jakarta.

Berdasarkan hasil analisis variabel iklim organisasi mempunyai rerata empirik $(\mathrm{ME})=159.72$ dan rerata hipotetik $(\mathrm{MH})=171$ yang berarti iklim organisasi pada subjek penelitian tergolong sedang. Variabel stres kerja mempunyai rerata empirik $(\mathrm{ME})=73.50$ dan rerata hipotetik $(\mathrm{MH})=123.4$ yang berarti stres kerja pada subjek penelitian tergolong sedang.

Berdasarkan hasil penelitian lain juga menemukan bahwa perawat yang bekerja diruang VIP memiliki persepsi yang sangat baik mengenai kondisi lingkungan kerjanya. Hal ini disebabkan karena di ruang VIP, biasanya perawat merawat pasien dengan kondisi yang sudah lebih baik. Sehingga stres kerja yang dialami oleh perawat yang bekerja diruang VIP pun cenderung rendah.

\section{Saran} dari penulis.

Untuk penelitian selanjutnya agar lebih sempurna, maka berikut beberapa saran

1. Bagi subjek penelitian, bila mengalami stres saat melakukan pekerjaan bisa menekan stres tersebut dengan baik melalui teknik relaksasi dan pernafasan. 
2. Bagi pihak RS X Jakarta, diharapkan agar mempertimbangkan kembali kebijakan tentang peniadaan jaminan kesehatan bagi keluarga perawat karena hal itu merupakan salah satu faktor untuk meningkatkan kepuasan kerja perawatnya.

3. Bagi peneliti selanjutnya, diharapkan agar dapat menemukan atau mengikutsertakan variabel lain yang memiliki hubungan dengan stres kerja seperti dukungan sosial, budaya organisasi, disiplin kerja, dan sebagainya. Penelitian tersebut dapat menjadi studi banding dan memberikan masukan-masukan lain yang berguna bagi peneliti selanjutnya maupun pengembangan ilmu pengetahuan.

\section{DAFTAR PUSTAKA}

Azwar, Saifuddin. 2009. Metode Penelitian. Yogyakarta: Pustaka Pelajar

Fatma, A.M, Gafar, Y.A., \& Abd Alkader, W.M. 2011. Pediatric nurses' stresses in intensive care units and its related factors. Journal of American Science, 7 (9):304-315].(ISSN : 1545-1003).

Handoko, T Hani. 2008. Manjemen Personalia. Yogyakarta : BPFE Yogyakarta.

Hasibuan, Malayu. 2012. Manajemen Sumber Daya Manusia. Edisi Revisi. Jakarta : Bumi Aksara.

Hermita. 2011. Pengaruh Stres Kerja Terhadap Kinerja Karyawan.Skripsi. Makassar: FE-UNHAS.

Idrus, Muhammad. 2008. Implikasi Iklim Organisasi Terhadap Kepuasan Kerja dan Kualitas Kehidupan Kerja Karyawan. Semarang : Jurnal Psikologi UNDIP ISSN 2302-1098.

Mavis, T. 2011. Percieved occupational stressors, stress and coping strategies among registered nurses in the tema metropolitan assembly. Tesis. University of Education Winneba: Published.

Notoatmodjo, S. 2010. Metodologi Penelitian Kesehatan. Jakarta: Rineka Cipta.

Periantalo, Jelpa. 2017. Statistika Dasar untuk Psikologi. Yogyakarta : Pustaka Pelajar.

Robbins, Stephen P, Timothy A. Judge. 2008. Perilaku Organisasi. Jakarta : Salemba Empat.

Sugiyono. 2014. Metode Penelitian \& Pengembangan Research and Development. Jakarta : Alfabeta.

Wirawan. 2008. Budaya dan Iklim Organisasi. Jakarta: Salemba Empat.

Yana, Dewi. 2014. Stres Kerja pada Perawat Instalasi Gawat Darurat di RSUD Pasar Rebo., Jakarta : Dinas Kesehatan DKI. 